\title{
Phenol and Benzoic Acid Degradation by Pseudomonas aeruginosa
}

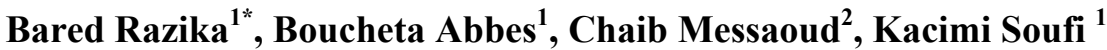 \\ ${ }^{1}$ Laboratory of materials and catalysis, Faculty of Sciences, Djilali Liabes University, Sidi Bel-Abbès, Algeria \\ ${ }^{2}$ Laboratory of Environmental Chemistry, Faculty of Science, University Ibn Khaldoun, Tiaret, Algeria \\ E-mail: Hibatelrahmane@yahoo.fr \\ Received June 11, 2010; revised June 22, 2010; accepted June 28, 2010
}

\begin{abstract}
The present work attempts to solve pollution problems in watery surroundings by aromatic compounds such as the phenol and the benzoic acid. Several ways of elimination of these compounds were the object of different research among which is the use of bacteria. In this framework, Pseudomonas aeruginosa bacterium is used to eliminate phenol and the benzoic acid. This made it possible to isolate the Pseudomonas aeruginosa bacterium directly on the nourishing environment containing phenol and benzoic acid as source of energy then the bacteria is incubated at $37^{\circ} \mathrm{C}$ during a minimal duration of four days. Furthermore, we studied the influence of the Pseudomonas aeruginosa bacterium on the deterioration of an area exposed to a phenol and the benzoic acid concentration. Results obtained at the time of the different experimentations clearly show that phenol and the benzoic acid were eliminated by the Pseudomonas aeruginosa bacterium. However, it was noted that during the various investigations the bacterium Pseudomonas aeruginosa develops better in a phenol milieu and therefore degrades phenol more than benzoic acid.
\end{abstract}

Keywords: Acid Benzoic, Degradation, Pseudomonas Aeruginosa, Phenol.

\section{Introduction}

E Phenol and phenolic compounds are important for many industries, which are involved in pesticide, tincture, bakelite, and medicine extensively. Therefore, a large amount of phenol and phenolic compounds are effused into stream and soil, and have badly polluted the environment [1]. Phenol is toxic to most microorganisms and potentially carcinogenic to humans [2]. Phenols are present in wastewater of various industries, such as refineries $(6-500 \mathrm{mg} / \mathrm{l})$, coking operations $(28-3900 \mathrm{mg} / \mathrm{l})$, coal processing $(9-6800 \mathrm{mg} / \mathrm{l})$, and manufacture of petrochemicals (2.8-1220 mg/l) [3].

Benzoic acid is a common additive for preserving foods, fats, fruit juices, alkaloid solutions, and curing tobacco. A major source of benzoic acid and its derivatives released into the aquatic environments are from the effluents of coal refining, paper and pulp mills, and in agricultural runoff [4]. Moreover, the wastewater discharged from processes of manufacture and application can pollute water, soil and atmosphere. The concentration of benzoic acid was found to range from 10 to 27500 $\mu \mathrm{g} / \mathrm{L}$ in the groundwater [5].

Different treatment methods are available for reduction of phenol content in wastewater. The technologies for the treatment of wastewater containing phenol include chlorination, ozonation, adsorption, solvent extraction, membrane process, coagulation, flocculation and biological treatment [6] and compared with physicochemical methods, the biodegradation methods of phenol reduction is universally preferred, because of lower costs and the possibility of complete mineralization [7] The use of microorganisms to degrade aromatic pollutants is an interesting low-cost approach for the treatment of industrial sewage disposal, contaminated sediments, soil and groundwater. Typically, biodegradation is practiced by providing favorable environmental conditions in order to stimulate the removal of pollutants [8].

Many aerobic phenol-degrading microorganisms were isolated and the pathways for the aerobic degradation of phenol are now definitely well established. The first step consists of oxygenation of phenol by phenol hydroxylase enzymes to form catechol, followed by ring cleavage adjacent to, or in between, the two hydroxyl groups of 
catechol. Phenol hydroxylases ranging from simple flavoprotein monooxygenases to multi component hydroxylases, as well as the genes coding for these enzymes, were described for few aerobic phenol-degrading microorganisms [9].

In this study, we report the biodegradation of benzoic acid and phenol at high initial concentrations. The biodegradation of these compounds was investigated individually using Pseudomonas aeroginosa. One of the purposes of this study was to biodegrade benzoic acid and phenol in short times and to obtain more information on interactions among aromatics during the biodegradation at high initial concentrations.

\section{Materials and Methods}

\subsection{Microorganism and Growth Medium}

Isolation has been realized directly on the King A and King B medium from urban wastewaters. Incubation is done at $37^{\circ} \mathrm{C}$ during 4 days.

After blue colony apparition in the King A medium and the red colony In the King B medium, Pseudomonas aeruginosa bacterium were added to the polluted water that contains the necessary mineral salts to the growth of the bacterium: $\mathrm{KH}_{2} \mathrm{PO}_{4}=1.7 \mathrm{~g} / 1, \mathrm{~K}_{2} \mathrm{HPO}_{4}=4.3 \mathrm{~g} / 1$, $\left(\mathrm{NH}_{4}\right)_{2} \mathrm{SO}_{4}=2.69 \mathrm{~g} / 1, \mathrm{CaCl}_{2}=0.03 \mathrm{~g} / 1, \mathrm{MgSO} 4=0.2 \mathrm{~g} / \mathrm{l}$ (Table 1), phenol and the benzoic acid have been used as the only source of carbon and energy. The solution sterilized to the autoclave and the incubation is done at $37^{\circ} \mathrm{C}$, the reading is done after $24 \mathrm{~h}$.

\subsection{Cell Density Measurement}

Bacterial growth was measured spectrophotometrically by optical density at $600 \mathrm{~nm}\left(\mathrm{OD}_{600}\right)$ [11].The transformation of DO into $\mathrm{UFC} / \mathrm{ml}$ is made by the relation: $\mathrm{DO}=0.7 \longrightarrow 10^{8} \mathrm{UFC} / \mathrm{ml}[12]$

\subsection{Chemicals}

Benzoic acid and phenol were used as the carbon sources, and all the solutions/media were made in double distilled

Table 1. Composition of the synthetic medium [10].

\begin{tabular}{lc}
\hline Compound & Concentration $\mathrm{g} / 1$ \\
\hline Phenol and benzoic acid & Variable \\
$\mathrm{KH}_{2} \mathrm{PO}_{4}$ & 1.7 \\
$\mathrm{~K}_{2} \mathrm{HPO}_{4}$ & 4.3 \\
$\left(\mathrm{NH}_{4}\right)_{2} \mathrm{SO}_{4}$ & 2.69 \\
$\mathrm{CaCl}_{2}$ & 0.03 \\
$\mathrm{MgSO}_{4}$ & 0.2 \\
\hline
\end{tabular}

water.

\subsection{Effect of pH on Phenol and Benzoic Acid Biodegradation}

To value the effect of the $\mathrm{pH}$ on the biodegradation of the two pollutants by Pseudomonas aeruginosa we prepared phenol and benzoic acid of the same $20 \mathrm{mg} / \mathrm{l}$ concentration in addition to necessary mineral salts to the growth of Pseudomonas aeruginosa. The $\mathrm{pH}$ was fixed to the different values 5.6, 7 and 8 , and every solution was put in contact with a number of Pseudomonas aeruginosa of $0.047 .10^{8} \mathrm{UFC} / \mathrm{ml}$ and submitted to agitation then incubated to $37^{\circ} \mathrm{C}$.

After 24 hours, the mixture of every solution was centrifuged at $4000 \mathrm{~g}$ for $15 \mathrm{~min}$; the degraded quantity of the compound was determined by the equation obtained by standardization curves.

\subsection{The Effect of Initial Concentration on Phenol and Benzoic Acid Biodegradation}

To study the effect of the concentration of the two compounds on the biodegradation by Pseudomonas aeruginosa, we prepared phenol solutions and benzoic acid to different concentrations of 10, 50, 70,80 mg/l. After that, volume of every solution was $50 \mathrm{ml}$, which we mixed with $0.047 .10^{8} \mathrm{UFC} / \mathrm{ml}$ of Pseudomonas aeruginosa and submitted to agitation and incubation for $24 \mathrm{~h}$.

\section{Results and Discussions}

After the biodegradation of $10,50,70$ and $80 \mathrm{mg} / \mathrm{l}$ phenol $10,50,70$ and $80 \mathrm{mg} / 1$ benzoic acid were conducted, the results obtained for phenol and benzoic acid biodegradation experiments are shown in Figures 1,2 respectively. These substrates were completely biodegraded except $80 \mathrm{mg} / \mathrm{l}(87.22 \%)$ phenol and $80 \mathrm{mg} / \mathrm{l}(81.25 \%)$ benzoic acid. Growth was apparent after a lag period and was exactly mirrored by phenol or benzoic acid consumption. The results showed that the lag period, the biodegradation time, and the number of microorganism increased on increasing the substrate concentrations. Also, the biodegradation time of benzoic acid was lower than the biodegradation time of phenol. It became obvious that microorganism used phenol as sole carbon and energy source better than benzoic acid.

The biodegradation times were first increased then decreased by increasing the concentration of phenol and benzoic acid. At low substrate concentrations, the biodegradation times of these compounds were, for example, 10 and $50 \mathrm{mg} / 1$ phenol were biodegraded in $96 \mathrm{~h}, 120 \mathrm{~h}$ 


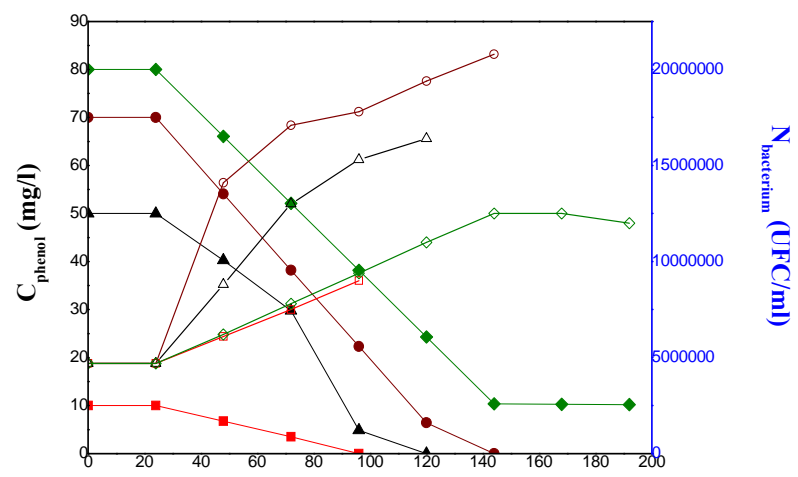

Figure 1. The biodegradation of $10(\bullet), 50(\Delta), 70(\bullet)$ and $80(\diamond) \mathrm{mg} / \mathrm{l}$ phenol, and the bacteria number for $10(\square), 50$ $(\Delta), 70(\circ)$ and $80(\diamond) \mathrm{mg} / \mathrm{l}$ phenol.

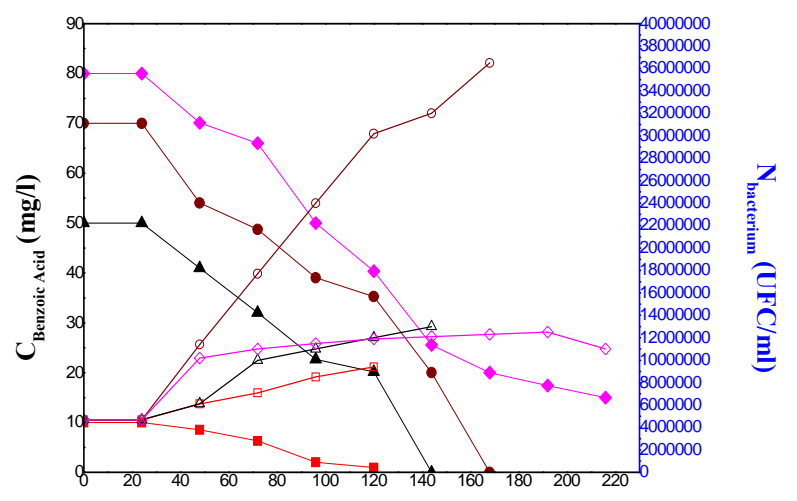

Figure 2. The biodegradation of $10(\square), 50(\Delta), 70(\bullet)$ and 80 ( $\diamond) \mathrm{mg} / \mathrm{l}$ benzoic acid and the bacteria number for 10 ( $\square$ ), $50(\Delta), 70(\circ)$ and $80(\diamond) \mathrm{mg} / \mathrm{l}$ benzoic acid.

respectively and $10,50 \mathrm{mg} / \mathrm{l}$ benzoic acid were biodegraded in $120 \mathrm{~h}, 140 \mathrm{~h}$ respectively.

In addition, the microorganism number obtained increased by increasing the concentration of the compounds, but there was no important increase in the microorganism number at the high substrate concentration of phenol and benzoic acid. For example $0.11 .10^{8}$ $\mathrm{UFC} / \mathrm{ml}$ as obtained from the biodegradation of $80 \mathrm{mg} / \mathrm{l}$ phenol and $0.9 .10^{8} \mathrm{UFC} / \mathrm{ml}$ from the biodegradation of $10 \mathrm{mg} / \mathrm{l}$ (Figure 1) and because of that, the biodegradation was decreased at the high concentrations of these compounds. These results show that the microorganism was inhibited by the presence of the high substrate concentrations.

The results for effect of $\mathrm{pH}$ on phenol and benzoic acid biodegradation experiments are shown in Figures 3,4 respectively.

The degradation time of phenol for $\mathrm{pH} 5.6,8$ and 7 was $96 \mathrm{~h}, 120 \mathrm{~h}, 72 \mathrm{~h}$ respectively.

Results show that phenol degradation is faster at $\mathrm{pH} 7$ because it is the appropriate $\mathrm{pH}$ for the growth of Pseudomonas aeruginosa.

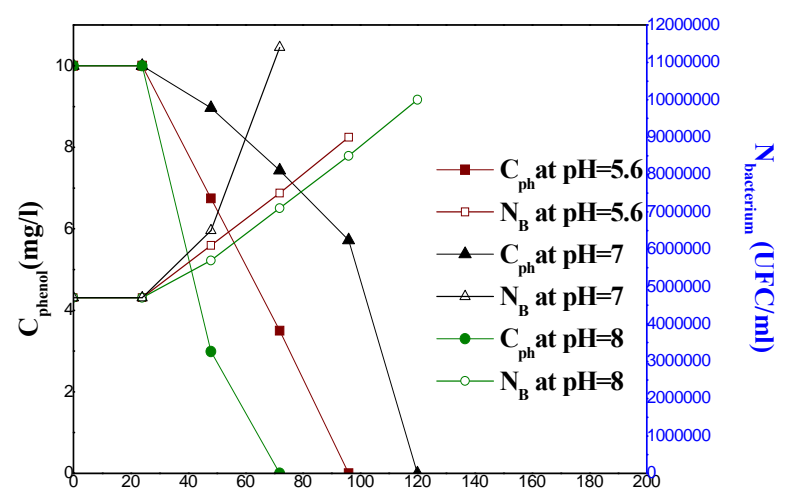

Figure 3. The effect of pH on phenol biodegradation.

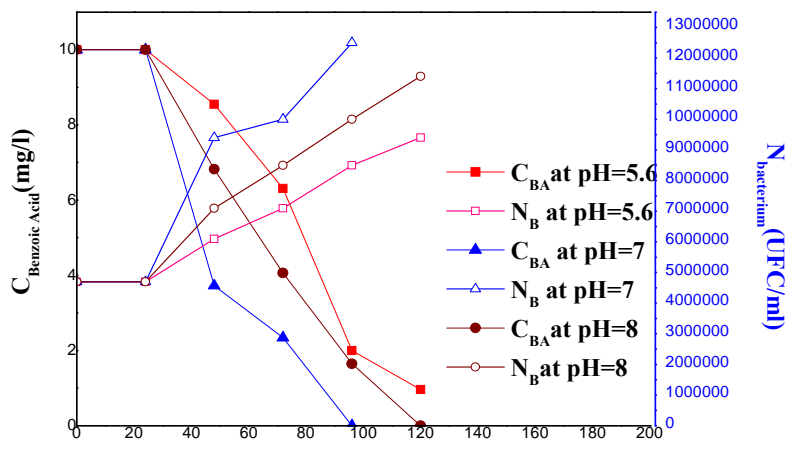

Figure 4. The effect of pH on benzoic acid biodegradation.

Finally, the degradation time for benzoic acid for $\mathrm{pH}$ 5.6, 8 and 7 was 120 h, $96 \mathrm{~h}$, and $120 \mathrm{~h}$ respectively. We notice that Pseudomonas aeruginosa totally destroyed the phenol and benzoic acid quantity in a short degradation time at $\mathrm{PH}=7$.

\section{Conclusions}

Pseudomonas aeruginosa bacterium developed better in a phenolic medium and therefore damaged the phenol more than the benzoic acid did because the presence of $\mathrm{COOH}$ grouping functional on the benzene cycle had an influence on the bacterium degradation capacity.

Phenol and benzoic acid degradation is faster at $\mathrm{PH}=$ 7 because it is the appropriate $\mathrm{pH}$ for the growth of the Pseudomonas aeruginosa bacterium.

However, Pseudomonas aeroginosa isolated in this study could not degrade very high concentrations of phenol and benzoic acid completely (> $80 \mathrm{mg} / \mathrm{l})$.

\section{References}

[1] G. Wei, J. Yu, Y. Zhu, W. Chen and L. Wang, "Characterization of Phenol Degradation by Rhizobium Sp. CCNWTB 701 Isolated from Astragalus Chrysopteru in Mining Tailing Region,” Journal of Hazardous Materials 
Vol. 151, No. 1, 2008, pp. 111-117.

[2] K. L. Ho, B. Lin, Y. Y. Chen and D. J. Lee, "Biodegradation of Phenol Using Corynebacterium Sp. DJ1 Aerobic Granules," Bioresource Technology, Vol. 100, No. 21, 2009, pp. 5051-5055.

[3] G. Buscaa, S. Berardinelli, C. Resini and L. Arrighib Rodrigues, "Technologies for the Removal of Phenol from Fluid Streams: A Short Review of Recentdevlopement," Journal of Hazardous Materials, Vol. 160, No. 23, 2008, pp. 265-288.

[4] P. Y. Lee and C. Y. Chen, "Toxicity and Quantitative Structure-Activity Relationships, of Benzoic Acids to Pseudokirchneriella Subcapitata," Journal of Hazardous Materials, Vol. 165, No. 1-3, 2009, pp. 156-161.

[5] D. F. Goerlitz, D. E. Troutman and E. M. Godsy, "Migration of Wood-Preserving Chemicals in Contaminated Groundwater in a Sand Aquifer at Pensacola," Science \&.Technology, Vol. 15, No. 3-4, 1985, pp. 955-961.

[6] V. Arutchelvan, V. Kanakasabai, S. Nagarajan and V. Muralikrishnan, "Kinetics of High Strength Phenol Degradation Using Bacillus Brevis," Journal of Hazardous Materials, Vol. 129, No. 1-3, 2006, pp. 216-222.

[7] G. Wei, J. Yu, Y. Zhu, W. Chen and L. Wang, "Characterization of Phenol Degradation by Rhizobium Sp CCNWTB 701 Isolated from Astragalus Chrysopteru in
Mining Tailing Region," Journal of Hazardous Materials, Vol. 151, No. 1, 2008, pp. 111-117.

[8] A. Papazi and K. Barbieri, "Inductive and Resonance Effects of Substituents Adjust the Microalgal Biodegradation of Toxical Phenolic Compounds," Journal of Biotechnology, Vol. 135, No. 4, 2008, pp. 366-373.

[9] M. Afzal, S. Iqbal, S. Rauf and Z. M. Khalid, "Characteristics of Phenol Biodegradation in Saline Solutions by Monocultures of Pseudomonas Aeruginosa and Pseudomonas Pseudomallei," Journal of Hazardous Materials, Vol. 149, No. 1, 2007, pp. 60-66.

[10] Á. M. G. Monteiro, R. A. R. Boaventura and A. E. Rodrigues, "Phenol Biodegradation by Pseudomonas Putida DSM 548 in a Batch Reactor," Biochemical Engineering Journal, Vol. 6, No. 1, 2000, pp. 45-49.

[11] Y. Zheng, D. Liu, H. Xu, Y. Zhong and Y. Yuan, "Biodegradation of P-Nitrophenol by Pseudomonas Aeruginosa HS-D38 and Analysis of Metabolites with HPLCESI/MS," International Biodeterioration \& Biodegradation, Vol. 63, No. 8, 2009, pp. 1125-1129.

[12] F. Hamadi, H. Latrache, E. Mliji and B. mallouki, "Adhésion de staphylococus aureus au verre et au teflon," Rcv. Microbiol, Ind , San et Environ, Vol. 3, No. 1, 2009, pp. 1-16. 